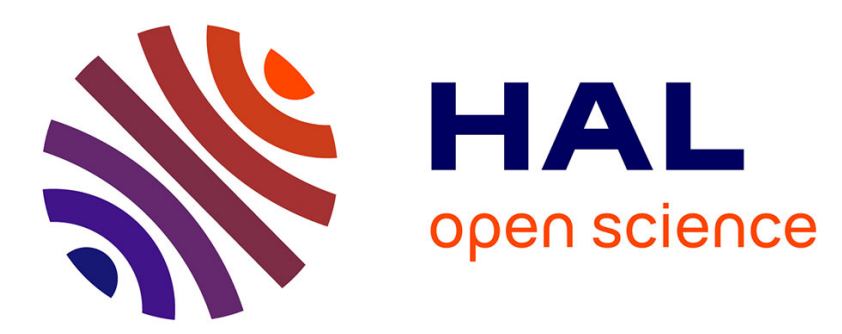

\title{
Mechanism of Thermal Decomposition of Palladium $\beta$-Diketonates Vapour on Hot surface
}

P. Semyannikov, V. Grankin, I. Igumenov, A. Bykov

\section{To cite this version:}

P. Semyannikov, V. Grankin, I. Igumenov, A. Bykov. Mechanism of Thermal Decomposition of Palladium $\beta$-Diketonates Vapour on Hot surface. Journal de Physique IV Proceedings, 1995, 05 (C5), pp.C5-205-C5-211. 10.1051/jphyscol:1995523 . jpa-00253848

\section{HAL Id: jpa-00253848 https://hal.science/jpa-00253848}

Submitted on 1 Jan 1995

HAL is a multi-disciplinary open access archive for the deposit and dissemination of scientific research documents, whether they are published or not. The documents may come from teaching and research institutions in France or abroad, or from public or private research centers.
L'archive ouverte pluridisciplinaire HAL, est destinée au dépôt et à la diffusion de documents scientifiques de niveau recherche, publiés ou non, émanant des établissements d'enseignement et de recherche français ou étrangers, des laboratoires publics ou privés. 


\title{
Mechanism of Thermal Decomposition of Palladium $\beta$-Diketonates Vapour on Hot Surface
}

\author{
P.P. Semyannikov, V.M. Grankin, I.K. Igumenov and A.F. Bykov \\ Institute of Inorganic Chemistry, Lavrentieva, 3, Novosibirsk, 630090, Russia
}

\begin{abstract}
The processes of thermal decomposition of palladium(II) $\beta$-diketonate complexes were investigated by a high-temperature mass spectrometric method with the use of a high-temperature molecular beam source. It was established that decomposition of the palladium complexes in gas phase processes proceeds by a radical mechanism and depends on temperature. For an additional proof of the existence of the radical particles the spin trap method was applied with a mass spectrometric identification of adducts. The following order of thermal stability of the complexes in gas phase was established: $\mathrm{Pd}(\mathrm{hfac})_{2}>\mathrm{Pd}(\mathrm{tfac})_{2}>\mathrm{Pd}(\mathrm{dpm})_{2}>\mathrm{Pd}(\mathrm{acac})_{2}$. This order is reverse to the thermal stability in a solid state. The thermal decomposition of $\mathrm{Pd}(\mathrm{aa})_{2}$ and $\mathrm{Pd}(\mathrm{hfa})_{2}$ complexes in deuterium showed that the deuterium presence strongly accelerates the decomposition processes.
\end{abstract}

\section{INTRODUCTION}

The noble metal $\beta$-diketonates are one of the most attractive classes of volatile compounds for CVD of metal films and coatings. The study of the thermal behaviour and the destruction mechanism of the precursors is important for the choice of deposition conditions for films and coatings. The differential thermal analysis method is practically hardly suitable for the study of such volatile compounds as $\beta$-diketonates of palladium and platinum. Moreover, the results obtained by the DTA method concern the compounds in a crystal state and can hardly be extended to real conditions of CVD processes. The mass spectrometric method is more advanced for thermal stability studies of $\beta$-diketonates in the gas phase. There are only a few reports in the literature where this method was used for the analysis of gaseous products of decomposition of metal $\beta$-diketonates [1-5].

The standard point of view is that the thermal decomposition of metal $\beta$-diketonates is of a radical character $[6,7]$, although there is no experimental confirmation of this opinion.

The purpose of this work is the study of the thermal stability and products of decomposition of the $\beta$-diketonates of palladium in the gas phase by the mass spectrometric method to find out the destruction mechanism of these compounds.

\section{EXPERIMENTAL}

For the study of the thermal destruction processes of palladium complexes in the gas phase, we used the MI-1305 (Russia) static type mass spectrometer with a mass resolution of 600 at an ionizing voltage of $75 \mathrm{eV}$. The device was equipped with a two-temperature Knudsen cell made of stainless steel. The compound under study was placed into the evaporation chamber, the chamber was evacuated and heated up to a certain constant temperature corresponding to a saturated vapour pressure of $10^{-3}-10^{-2}$ Torr. The 
temperature of the outlet chamber could be changed in a step like manner over a wide temperature range. The accuracy of the temperature maintenance for each chamber was $\pm 0.1^{\circ} \mathrm{C}$. After each step like increase in the outlet chamber temperature the full mass spectrum was recorded. The injection system was described in detail in $[4,8]$.

We used the spin trap method for an additional confirmation of the presence of radical particles in the gaseous products of thermal decomposition. Its essence consists in the interaction of unstable radical gaseous products with a stable radical (spin trap). As a result stable adducts are formed which can be identified both by ESR and mass spectrometry. The compound $\mathrm{C}_{6} \mathrm{H}_{5} \mathrm{CH}=\mathrm{N}(\mathrm{O}) \mathrm{C}\left(\mathrm{CH}_{3}\right)_{3}$ (PBN) was used as a spin trap.

As the decomposition process of palladium $\beta$-diketonates takes place at temperatures obviously exceeding the temperature interval of the spin trap stability a special vacuum cell was constructed. The design of this cell permitted to quickly heat only the investigated compound up to the decomposition temperature. The $\beta$-diketonate and PBN were put separately on two thin porous glass plates. The plates were placed into the vacuum cell (pressure about of $10^{-2}$ Torr) and disposed the parallel to one another at a distance from 6 up to $20 \mathrm{~mm}$. The first plate with the $\beta$-diketonate was heated up to the decomposition temperature by IR-radiation. The gaseous products of the thermal decomposition reacted with PBN on the surface of the second plate.

The adducts were dissolved in chloroform or acetone, dried and then their composition was analyzed by mass spectrometric method. In this case under a constant temperature of the outlet chamber the temperature of the evaporation chamber was slowly increased. The comparison of mass spectra of the adducts picked up directly from the surface of the second glass plate and those from the solution showed identical.

\section{RESULTS AND DISCUSSION}

\subsection{Mass spectrometric analysis of decomposition products}

In the present work the decomposition in the gas phase of the palladium hexafluoroacetylacetonate $\left(\mathrm{Pd}(\mathrm{hfac})_{2}\right)$, palladium trifluoroacetylacetonate $\left(\mathrm{Pd}(\mathrm{tfac})_{2}\right)$, palladium dipivaloylmethanate $\left(\mathrm{Pd}(\mathrm{dpm})_{2}\right)$ and palladium acetylacetonate $\left(\operatorname{Pd}(\mathrm{acac})_{2}\right)$ with a general formula $\mathrm{PdL}_{2}$, where $\mathrm{L}=\mathrm{R}^{1} \mathrm{C}(\mathrm{O}) \mathrm{CHC}(\mathrm{O}) \mathrm{R}^{2}\left(\mathrm{R}^{1}, \mathrm{R}^{2}\right.$ $\left.=\mathrm{CH}_{3}, \mathrm{C}\left(\mathrm{CH}_{3}\right)_{3}, \mathrm{CF}_{3}\right)$, are investigated. The analysis of the mass spectra has shown that the major fragmentation pathways are similar for all the investigated compounds. In the gas phase under an electron impact a consecutive loss of ligands takes place and the following ions are observed in the mass spectra $\left[\mathrm{PdL}_{2}\right]^{+},[\mathrm{PdL}]^{+},[\mathrm{Pd}]^{+}$and $[\mathrm{LH}]^{+}$. The most intensive metal-containing ions are the molecular ions $\left[\mathrm{PdL}_{2}\right.$ ]$^{+}$for $\mathbf{L}=$ acetylacetonate, dipivaloylmethanate and trifluoracetylacetonate. The ions $[\mathrm{Pd}]^{+}$and $[\mathrm{Pd}(\mathrm{L}$ $\left.\left.\mathrm{CF}_{3}\right)\right]^{+}$are the most intensive in the $\mathrm{Pd}(\mathrm{hfac})_{2}$ mass spectrum. The intensity of the molecular ions is about $40 \%$ of total intensity of all metal-containing ions for $\operatorname{Pd}(\mathrm{acac})_{2}, \operatorname{Pd}(\mathrm{dpm})_{2}, \operatorname{Pd}(\mathrm{tfac})_{2}$ and about $15 \%$ for $\mathrm{Pd}(\mathrm{hfac})_{2}$. The intensity of the ion peak $[\mathrm{LH}]^{+}$is $20-30 \%$ of the intensity of the molecular ion peak for all compounds.

With increase in temperature of reactor starting from some threshold value a decrease in the molecular peak intensity for each compound with a simultaneous increase in the intensity of peaks $[\mathrm{LH}]^{+}$and $[\mathbf{L}]^{+}$is observed. It corresponds to the decomposition of these molecules. Ratio of intensities of metal-containing ions with temperature remains constant (besides $\mathrm{Pd}(\mathrm{dpm})_{2}$ case), i.e all these ions have the same molecular precursor.

Fig. 1a shows that the vapour of $\mathrm{Pd}(\mathrm{hfac})_{2}$ decomposes at a temperature higher than $380^{\circ} \mathrm{C}$. The elimination of the free ligand (corresponding ion $[\mathrm{LH}]^{+}, \mathrm{m} / \mathrm{z} 208$ ) occurs in the temperature range $380-$ $400^{\circ} \mathrm{C}$. An increase in the ion peaks $\left[\mathrm{CHCO}^{+}(\mathrm{m} / \mathrm{z} 41),\left[\mathrm{CO}_{2}\right]^{+}(\mathrm{m} / \mathrm{z} 44),\left[\mathrm{CF}_{3}\right]^{+}(\mathrm{m} / \mathrm{z} 69),\left[\mathrm{OCF}_{3}\right]^{+}\right.$ $\left(\mathrm{m} / z\right.$ 85) and $\left[C_{2} F_{5}\right]^{+}(\mathrm{m} / z 119)$ is simultaneously observed in the mass spectrum. Their intensities increase faster than the intensity of the $[\mathrm{LH}]^{+}$ion. These ion peaks, in our opinion. are the result of the destruction of an unstable particle $\mathrm{Pd}(\mathrm{hfac})$. A further growth of the temperature results in the appearance of the ion $[\mathrm{L}]^{+}(\mathrm{m} / \mathrm{z} 207)$ which we assign to the ligand radical $\mathrm{L}^{\prime}$ 


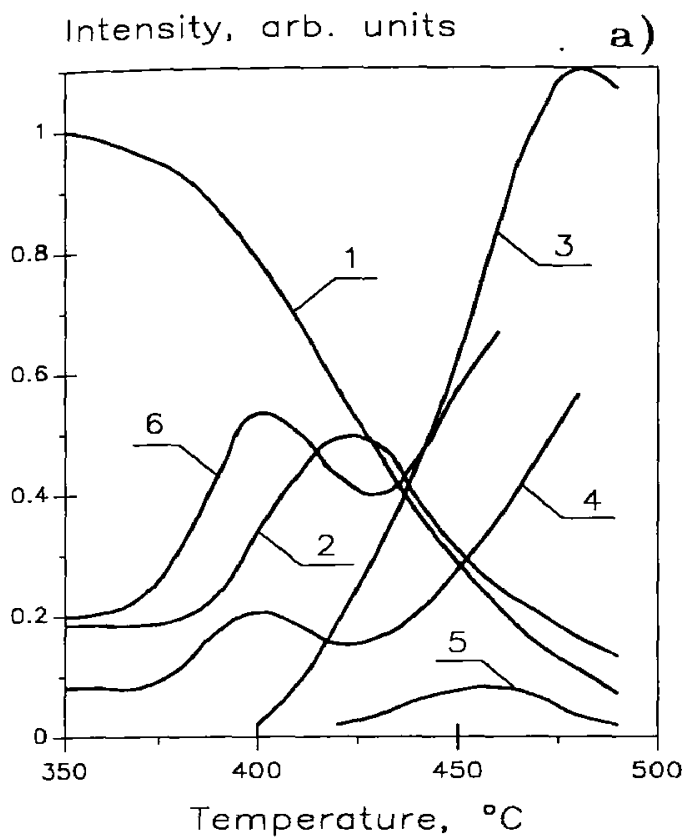

Intensity, arb. units

b)

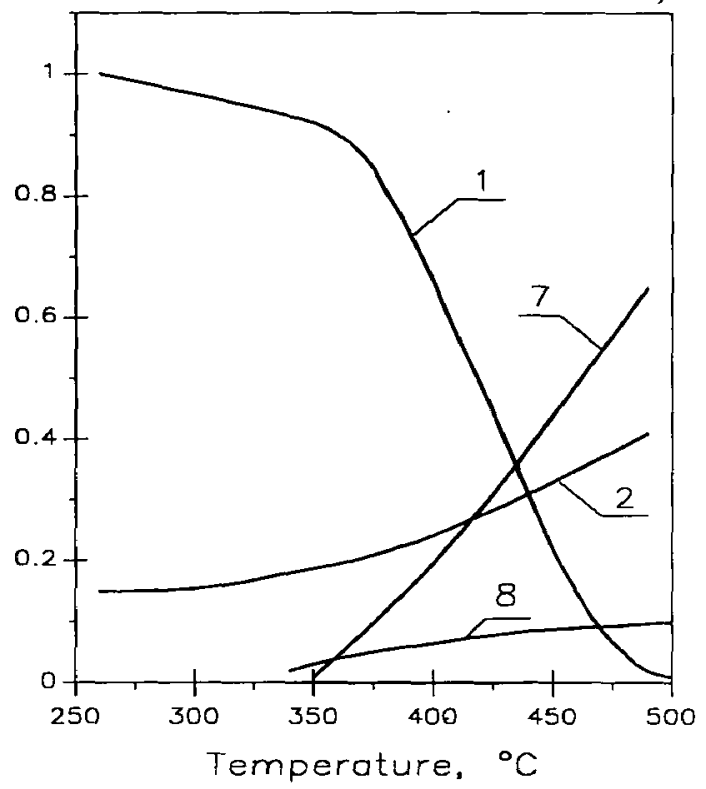

Figure 1: Temperature dependence of ion peak intensities corresponding to the main gaseous products of thermolysis of $\mathrm{Pd}(\mathrm{hfac})_{2}$ a) and $\mathrm{Pd}(\mathrm{tfac})_{2}$ b) vapour : $\left[\mathrm{PdL}_{2}\right]^{+}(1),[\mathrm{HL}]^{+}(2),[\mathrm{L}]^{+}(3),\left[\mathrm{CF}_{3}\right]^{+}(4),\left[\mathrm{C}_{5} \mathrm{HF}_{5} \mathrm{O}_{2}\right]^{+}(5),\left[\mathrm{OCF}_{3}\right]^{+}(6),[\mathrm{L}-\mathrm{H}]^{+}$ (7), $\left[\mathrm{C}_{4} \mathrm{HFO}_{2}\right]^{+}$(8).

Intensity, arb. units

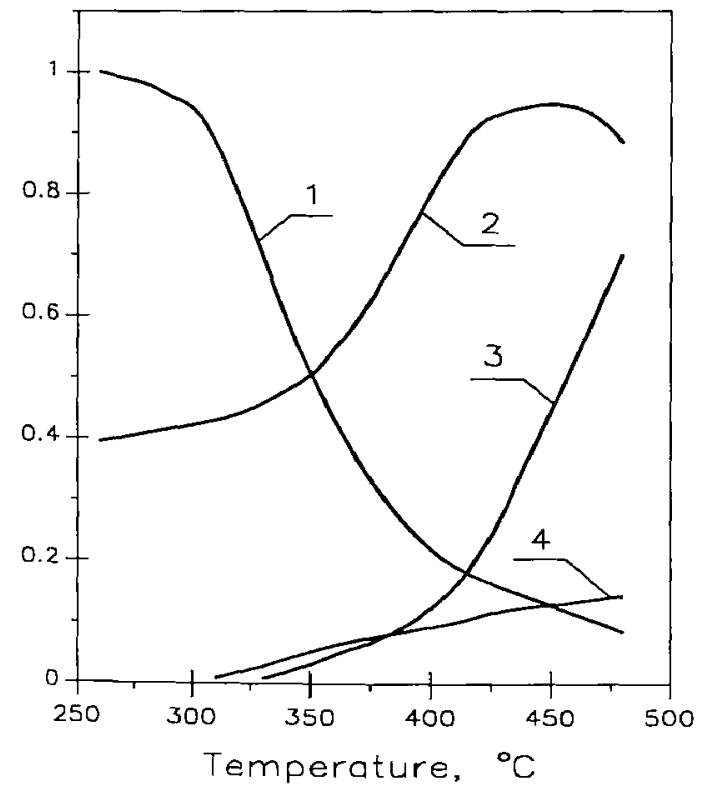

Intensity, arb. unuts

b)

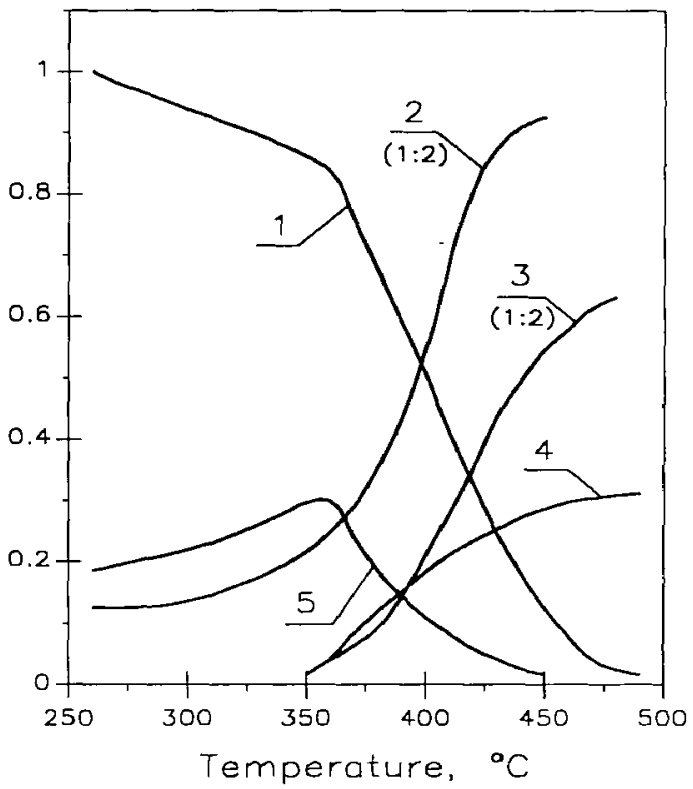

Figure 2: Temperature dependence of ion peak intensities corresponding to the main gaseous products of thermolysis of $\mathrm{Pd}(\mathrm{acac})_{2}$ a) and $\mathrm{Pd}(\mathrm{dpm})_{2}$ b) vapour: $\left[\mathrm{PdL}_{2}\right]^{+}(1),[\mathrm{HL}]^{+}(2),[\mathrm{L}-\mathrm{H}]^{+}(3),\left[\left(\mathrm{CH}_{3}\right)_{2} \mathrm{C}_{2} \mathrm{O}\right]^{+}(4),[\mathrm{PdL}]^{+}$(5). The scale is in brackets 
The radical mechanism of decomposition becomes prevailing with increasing temperature which is indicated by the maximum of the ion $[\mathrm{LH}]^{+}$and increase of the ion $[\mathrm{L}]^{+}$in the intensity curves. It should be noted, that with the growth of the ion $[\mathrm{L}]^{+}$peak intensity, there is observed an increase in the intensity of the ion $\left[\mathrm{LH}_{2}\right]^{+}(\mathrm{m} / \mathrm{z} 209)$ peak, which is also the product of the thermal destruction of $\mathrm{Pd}(\mathrm{hfac})_{2}$. At a temperature higher than $475^{\circ} \mathrm{C}$ the decomposition of particles $\mathrm{L}^{\prime}$ and $\mathrm{LH}_{2}$ is observed as is indicated by the fast decrease of these ion peak intensities with a corresponding sharp increase in the peaks $\left[\mathrm{C}_{2} \mathrm{~F}_{5}\right]^{+},\left[\mathrm{CO}_{2}\right.$ ]$^{+},\left[\mathrm{CF}_{3}\right]^{+}$. The intensity of the ion peak $\left[\mathrm{CF}_{3}\right]^{+}$passes through the maximum at a temperature of about $510^{\circ} \mathrm{C}$, which can be explained by a recombination of these radicals and a formation of a particle $\mathrm{C}_{2} \mathrm{~F}_{6}$ with a corresponding peak $\left[\mathrm{C}_{2} \mathrm{~F}_{5}\right]^{+}(\mathrm{m} / \mathrm{z} 119)$.

For the complexes $\mathrm{Pd}(\mathrm{tfac})_{2}$ and $\mathrm{Pd}(\mathrm{acac})_{2}$ the temperature thresholds of the gas phase decomposition are equal to $365^{\circ} \mathrm{C}$ and $305^{\circ} \mathrm{C}$, respectively. The decomposition processes of these compounds are similar to those described above and are presented in Fig. Ib and Fig. 2a. However, the ion peak $\left[\mathrm{LH}_{2}\right]^{+}$is not observed in the mass spectra of gaseous products of the decomposition. The ion peak [L-H] corresponding to a radical of the ligand was observed in the gaseous products in the case of $\operatorname{Pd}(\mathrm{tfac})_{2}$ $\mathrm{Pd}(\mathrm{acac})_{2}$ and $\mathrm{Pd}(\mathrm{dpm})_{2}$ decomposition.

The decomposition of molecules $\mathrm{Pd}(\mathrm{dpm})_{2}$ in the gas phase somewhat differs by the presence in the mass spectra of products of particles which were not observed in the previous experiments. Fig. $2 b$ shows the temperature thermal decomposition curves for $\operatorname{Pd}(\mathrm{dpm})_{2}$ vapour. A slow decrease in the intensity of the ion peak $\left[\mathrm{PdL}_{2}\right]^{+}$with a simultaneous increase in the intensity of the peaks $[\mathrm{LH}]^{+}(\mathrm{m} / \mathrm{z} 184)$ and $[\mathrm{PdL}]^{+}\left(\mathrm{m} / \mathrm{z} 293,{ }^{110} \mathrm{Pd}\right)$ occurs at temperatures of between $150^{\circ} \mathrm{C}$ and $360^{\circ} \mathrm{C}$. There is a fast decrease in the peak intensity of the ion $\left[\mathrm{PdL}_{2}\right]^{+}$at temperatures above $360^{\circ} \mathrm{C}$ with a corresponding increase in the peaks $[\mathrm{LH}]^{+}$and $[\mathrm{L}-\mathrm{H}]^{+}(\mathrm{m} / \mathrm{z} 182)$. This behaviour is similar to that observed during the decomposition of the $P d(h f a c)_{2}, P d(t f a c)_{2}$ and $\operatorname{Pd}(\mathrm{acac})_{2}$ complexes. Thus, the process of thermal decomposition of $\operatorname{Pd}(\mathrm{dpm})_{2}$ proceeds in two ways. The elimination of the free ligand LH and formation of $\mathrm{Pd}(\mathrm{dpm})$ occurs in the temperature range of $150-360^{\circ} \mathrm{C}$. The relative stability of this molecule, probably, takes place due to higher mobility of the $\mathrm{t}-\mathrm{Bu}$ groups in the $\mathrm{Pd}(\mathrm{dpm})_{2}$ molecule in comparison with the methyl group in $\operatorname{Pd}(\mathrm{acac})_{2}$ and the trifluoromethyl group in $\operatorname{Pd}(\mathrm{hfac})_{2}$. The process of thermal decomposition of $\operatorname{Pd}(\mathrm{dpm})_{2}$ vapour in the temperatures range higher than $360^{\circ} \mathrm{C}$ is similar to that described above for the $\operatorname{Pd}(\mathrm{hfac})_{2}$. $P d(t f a c)_{2}$ and $P d(a c a c)_{2}$ complexes.

\subsection{Kinetic parameters of decomposition processes}

The kinetic parameters of the processes under investigation were calculated by the temperature curves shown in Fig. 1, 2. The experiments performed at different evaporation temperatures, i.e. at different molecule concentrations in a reaction chamber, show that the curves do not change their shape and therefore they can be described by the first-order kinetic equation for an initial compound. Based on the balance equation for particles of initial compound in the reaction chamber (molecular flow and irreversibility of vapour thermolysis) for the rate constant of the first-order reaction, the following empirical formula is valid [4]:

$K=\left\{\left(A_{t}+A_{e}\right) *(T / m)^{1 / 2} *\left[\left(I_{o i} / I_{i}\right) *\left(T_{0} / T\right)^{1 / 2}-1\right]\right\} / V$,

where $A_{t}$ and $A_{e}$ are the constant factors in terms of gas flow conductivity $\left(F_{t}=A_{t} \star(T / m)^{1 / 2}\right)$ for a pipeline connecting the evaporation chamber with the reaction chamber and for a effusion outlet of this chamber, respectively (determined from the geometrical sizes); $I_{O i}$ is the intensity of the initial compound ion peak measured at any temperature $T_{0}$ before a threshold of thermal stability; $l_{i}$ is the current value of the ion peak intensity measured at temperature $T ; V$ is the volume of the reaction chamber; and $m$ is the molecular weight of the initial compound.

The temperature dependencies calculated for the rate constants of themal decomposition of palladium $\beta$-diketonate vapour in vacuum are shown in Fig.3. The effective values of parameters in the Arrhenius equation are given in Table 1. 


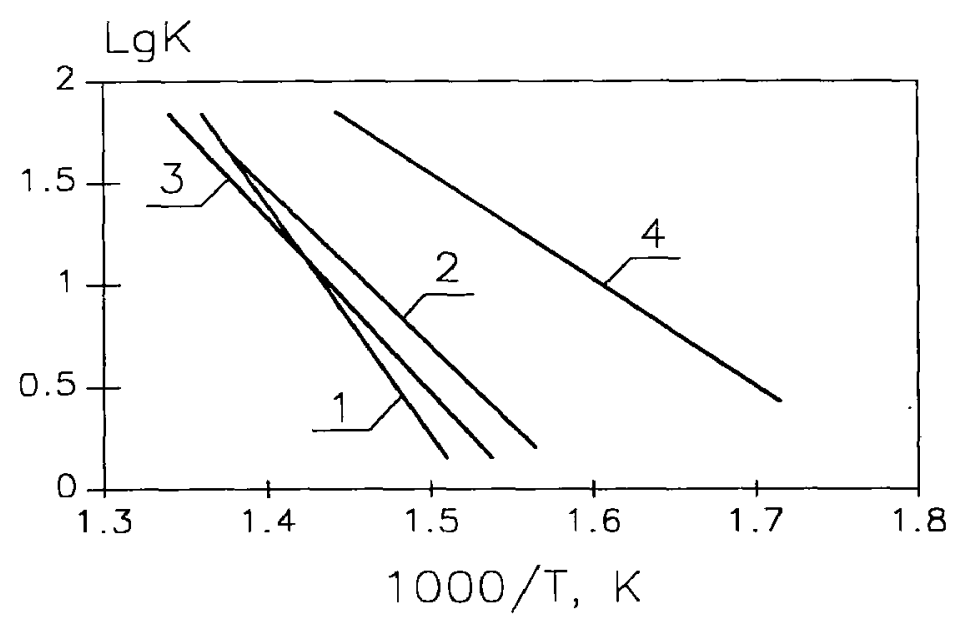

Figure 3: Dependence of rate constant on reciprocal temperature for the thermolysis of $\mathrm{Pd}(\mathrm{hfac})_{2} \quad(1), \operatorname{Pd}(\mathrm{tfac})_{2}(2)$, $\mathrm{Pd}(\mathrm{dpm})_{2}(3), \operatorname{Pd}(\mathrm{acac})_{2}(4)$.

Table 1: Effective values of Arrhenius parameters for palladium $\beta$-diketonate vapour thermolysis

\begin{tabular}{|l|l|l|l|l|}
\hline Compound & $P d(h f a c)_{2}$ & $P d(t f a c)_{2}$ & $P d(d p m)_{2}$ & $P d(a c a c)_{2}$ \\
\hline$E_{a}, \mathrm{~kJ} / \mathrm{mol}$ & $155 \pm 5.0$ & $134.5 \pm 6.7$ & $137.9 \pm 7.1$ & $120.7 \pm 7.5$ \\
\hline $\mathrm{K}_{\mathrm{a}}, \mathrm{s}^{-1}$ & $2.0 * 10^{12}$ & $7.2 * 10^{10}$ & $2.5 * 10^{11}$ & $2.6 * 10^{10}$ \\
\hline
\end{tabular}

\subsection{Investigation of $\mathrm{Pd}(\mathrm{hfac})_{2}$ decomposition by spin trap method}

It was established by the mass spectrometric analysis of adducts, formed by interaction of gaseuos products of the $\mathrm{Pd}(\mathrm{hfac})_{2}$ decomposition with the solid $\mathrm{PBN}$, that the following compounds are present: $\mathrm{PBN} * \mathrm{CF}_{3}, \mathrm{PBN} * \mathrm{hfac}, \mathrm{PBN} * \mathrm{Pd}(\mathrm{hfac})$ and PBN*Pd(hfac)-O. The initial compounds, $\mathrm{Pd}(\mathrm{hfac})_{2}$ and PBN, are also observed in mass spectrum. The molecular peak $\mathrm{m} / \mathrm{z} 246$ in a mass spectrum of a very low intensity, which depends weakly on temperature of the evaporation chamber in the temperature range 25$60^{\circ} \mathrm{C}$ corresponds to the compound $\mathrm{PBN} * \mathrm{CF}_{3}$. The peaks corresponding to the particles $\mathrm{CF}_{3}$ and $\mathrm{PBN}$ are rather intensive and increase with temperature faster than the peak $\mathrm{m} / z 246$. This is due, in our opinion, to the decomposition of $\mathrm{PBN}+\mathrm{CF}_{3}$ molecule. The assumed PBN-hfac molecule does not give the molecular peak $\mathrm{m} / \mathrm{z} 384$ under the electron impact. However, the presence of the ion peaks $\left[\mathrm{CF}_{3} \mathrm{COCHCH}_{3}\right]^{+}(\mathrm{m} / \mathrm{z}$ 154), $\left[\mathrm{CF}_{3} \mathrm{CON}\left(\mathrm{CH}_{3}\right) \mathrm{C}_{6} \mathrm{H}_{5}\right]^{+}(\mathrm{m} / \mathrm{z} 230),[\mathrm{PBN}-\mathrm{H}]^{+}(\mathrm{m} / \mathrm{z} 176),[\mathrm{LH}]^{+}(\mathrm{m} / \mathrm{z} 208)$ in the absence of metalcontaining particles in the gas phase gives grounds to assume that this molecule is one of the adducts. With the increase in the evaporation temperature, the intensity of these ion peaks also increases.

At $95^{\circ} \mathrm{C}$ the ion peaks corresponding to the particles PBN*Pd(hfac) $(\mathrm{m} / \mathrm{z} 494)$ and $\mathrm{PBN} \cdot \mathrm{Pd}(\mathrm{hfac})-\mathrm{O}(\mathrm{m} / \mathrm{z}$ 478) appear in the mass spectrum. The mass spectrometric investigation of the temperature dependencies for the saturated vapour pressure by the Knudsen method shows the specificity of these compounds. They begin to sublimate at the same temperature of $95^{\circ} \mathrm{C}$, the correspouding parameters of the sublimation processes are equal to $128.2 \pm 8.4$ and $76.7 \pm 4.2 \mathrm{~kJ} / \mathrm{mol}$ for $\mathrm{PBN} * \mathrm{Pd}(\mathrm{hfac})$ and $\mathrm{PBN} * \mathrm{Pd}(\mathrm{hfac})-\mathrm{O}$. These compounds decompose in the gas phase at a lower temperature than $\mathrm{Pd}(\mathrm{hfac})_{2}$ itself.

The occurrence of such thermolysis products as $\mathrm{CF}_{3}$ ', Pd(hfac) and hfac' was also confirmed by ESRspectrometry [9]. However, the interpretation of the obtained results was made possible with the mass spectrometric data only. 


\subsection{Decomposition of $P d(a c a c)_{2}$ and $P d(h f a c)_{2}$ in deuterium medium}

The results of the $\mathbf{P d}(\mathrm{acac})_{2}$ vapour decomposition in a deuterium medium are shown in Fig. 4 . It can be easily observed that the presence of deuterium in the reaction mixture essentially decreases the thermal stability of the initial compound. Only mono-deuterated and non-deuterated molecules of ligand were observed in the reaction products. The peak intensities of [Dacac $]^{+}$and [Hacac] $]^{+}$increase with temperature and tend to close values. At the same time the increase in inteusity of $3 \mathrm{~m} / \mathrm{z}$ peak, corresponding to mono. deuterated hydrogen molecules HD, is observed. An increase of deuterium concentration in the reaction mixture to ten times does not influence on the threshold temperature, but strongly accelerates the process of decomposition at the same temperatures and concentrations of initial complexes. Thus, along with mono-deuterated the double-deuterated molecules of free ligand are formed; their amount increases with the growth of deuterium concentration. The similar result was obtained for $\mathrm{Pd}(\mathrm{hfac})_{2}$ vapour decomposition, however, an interaction with deuterium occurs already at room temperature.

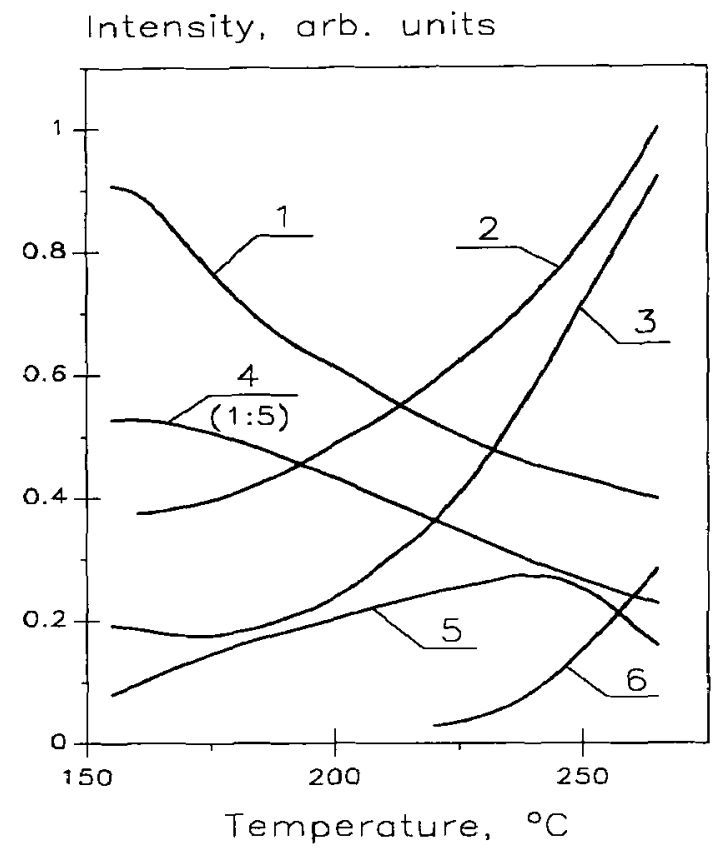

Figure 4: Temperature dependence of ion peak intensities corresponding to the main gaseous products of thermolysis of $\mathrm{Pd}(\mathrm{acac})_{2}$ vapour in deuterium: $\left[\mathrm{Pd}(\mathrm{acac})_{2}\right]^{+}(1),[\mathrm{Hacac}]^{+}(2),[\mathrm{Dacac}]^{+}(3),\left[\mathrm{D}_{2}\right]^{+}(4),\left[\mathrm{HD}^{+}(5),\left[\mathrm{CH}_{3} \mathrm{C}(\mathrm{O}) \mathrm{CD}_{2} \mathrm{C}(\mathrm{O}) \mathrm{CH}\right]^{+}\right.$ (6).

The values of threshold temperatures for investigated palladium complexes are represented in Table 2.

Table 2: Decomposition onset temperature of palladium(II) $\beta$-diketonates vapour in vacuum and deuterium nediun

\begin{tabular}{|l|c|c|c|c|}
\hline Compound & $P d(h f a c)_{2}$ & $P d(\text { tfac })_{2}$ & $P d(d p m)_{2}$ & $P d(a c a c)_{2}$ \\
\hline$T_{\text {dec }}, \pm 10^{\circ} \mathrm{C}$ (vacuum) & 380 & 365 & 360 & 305 \\
\hline$T_{\text {dec }, \pm 10^{\circ} \mathrm{C} \text { (deuterium) }}$ & 20 & - & - & 150 \\
\hline$T_{\text {dec }} \cdot$ (DTA in helium [10]) & 172 & 274 & 303 & 210 \\
\hline
\end{tabular}




\section{CONCLUSION}

Based on the analysis performed, we can conclude that the process of thermal decomposition of palladium $\beta$-diketonates under investigation proceeds in several parallel directions and can be described by the following scheme:

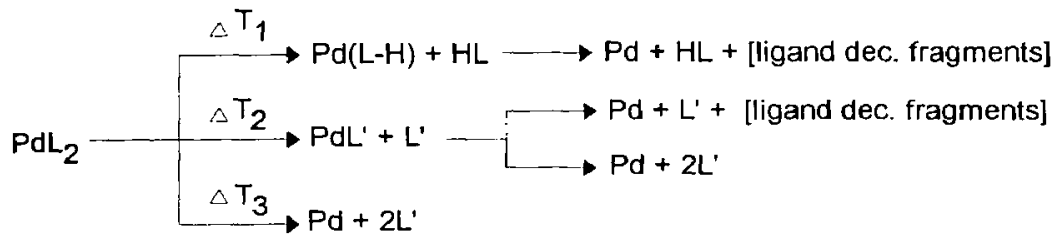

The decomposition process accompanied by elimination of free ligand and formation of the unstable molecule $\operatorname{Pd}(\mathrm{L}-\mathrm{H})$ takes place close to the decomposition threshold. The destruction of the latter is accompanied by formation of light organic products and radicals. The reaction rate increases with temperature, and the decomposition process proceeds by the radical mechanism with the breakage of metal-oxygen bonds.

The compounds under investigation can be arranged in a row according to their thermal stability in the gas phase as follows: $\mathrm{Pd}(\mathrm{hfac})_{2}>\mathrm{Pd}(\mathrm{tfac})_{2}>\mathrm{Pd}(\mathrm{dpm})_{2}>\mathrm{Pd}(\mathrm{acac})_{2}$.

As a criterion, we use the following threshold temperatures of destruction by the radical mechanism: $330^{\circ} \mathrm{C}$ for $\mathrm{Pd}(\mathrm{acac})_{2}, 340^{\circ} \mathrm{C}$ for $\mathrm{Pd}(\mathrm{dpm})_{2}, 350^{\circ} \mathrm{C}$ for $\mathrm{Pd}(\mathrm{tfac})_{2}$ and $400^{\circ} \mathrm{C}$ for $\mathrm{Pd}(\mathrm{hfac})_{2}$. Taking into account this fact, we can conclude that the row of thermal stability in the gas phase is reverse to the row of thermal stability in the solid state for the palladium $\beta$-diketonates, i.e., the introduction of trifluoromethyl groups into the ligand gives an increase in the thermal stability of gaseous molecules for the row of compounds under investigation. In the solid state, the introduction of the trifluoromethyl groups reduces the thermal stability of metal $\beta$-diketonates.

It should be noted that the row of thermal stability of the investigated palladium $\beta$-diketonates in the gas phase corresponds to the rows obtained from the thermochemical data on energies of the homolytical breakage of metal-ligand bonds for the complexes of copper, beryllium, and aluminium with various $\beta$-diketones [1I].

The data obtained should not be applied to other compounds of this class, since we know examples. where the decomposition proceeds by the intramolecular mechanism only with formation of free ligand and other molecular products [4].

\section{References}

[1] Hoene B.J.V., Charles R.G. and Hickam W.M., J. Phys. Chem. 62 (1958) 1098-1 101.

[2] Isakova V.G., Semyannikov P.P., Grankin V.M. and Igumenov I.K., Koord. Khim. 14 (1988) 57-62

(in Russian).

[3] Girichev G.V., Giricheva N.I., Belova N.V. et al., Zh. Neorg. Khim. 38 (1993) 647-652 (in Russian).

[4] Bykov A.F., Semyannikov P.P. and Igumenov I.K.,J. Thermal Anal. 38 (1992) 1463-1475.

[5] Bykov A.F., Semyannikov P.P. and Igumenov I.K.,J. Thermal Anal. 38 (1992) 1477-1486.

[6] Films and coatings deposition by decomposition of metal-organic compounds (Ed. by Razuvaev G.A. Nauka, Moscow, 1981) pp. 208-211.

[7] Malkerova I.P., Alikhanyan A.S., Sevastyanov V.G. et al., Zh. Neorg. Khim. 35 (1990) 413-418

[8] Grankin V.M. and Semyannikov P.P., Pribori i tekhnika experimenta 4 (1991) 129 (in Russian).

[9]. V.A.Nadolinny, P.P.Semyannikov, V.M.Grankin, I.K.Igumenov and A.F.Bykov, Izv. Sib. Otd. Ac. Nauk SSSR. 4 (1986) 45-53 (in Russian).

[10] Zharkova G.I., Igumenov I.K. and Tyukalevskaya N.M. Koord. Khim. 14 (1988) 67-74 (in Russian). [11] Fedotova N.E., Voityuk A.A.. Bliznyuk A.A. and Igumenov I.K.. Koord. Khim. 14 (1988) 1493-1506 (in Russian) 